\title{
EFEKTIVITAS PROGRAM BANGKIT BERDAYA DALAM MENINGKATKAN PARTISIPASI MASYARAKAT DI KECAMATAN KOTABARU KOTA JAMBI PROVINSI JAMBI
}

\author{
Oleh \\ Theresia Yulia Agustin ${ }^{1}$, \\ Muchlis Hamdi' ${ }^{2}$ Andi Masrich ${ }^{3}$ \\ 1) Pemerintah Kota Jambi \\ Program Magister Terapan Studi Pemerintahan Daerah Institut Pemerintahan Dalam Negeri \\ theresia_yulia3107@yahoo.com \\ ${ }^{2,3)}$ Institut Pemerintahan Dalam Negeri
}

\begin{abstract}
$T$ e Effectiveness of Bangkit Berdaya Powering Program in increasing community participation in the Kotabaru sub-district of Jambi City, Jambi Province. This research is motivated by the authors' interest in examining the problems that arise regarding the Effectiveness of the Risen Powering Program. From the results of interviews and preliminary observations, the authors found the problem Lack of community participation in the Kotabaru sub-district in the construction of infrastructure in the neighborhood.

This study intends to determine the extent of the effectiveness Bangkit Berdaya, supporting and inhibiting factors, and strategies in implementing the powerless rise program in Kotabaru sub-district, using the Effectiveness theory proposed by Gibson, Donnely and Ivancevich. The research method used in the preparation of this thesis is a descriptive research method with a qualitative approach. Data obtained is through literature study, observation, interview documentation.

The results of the study showed the effectiveness of the Risen Empowerment Program showed good results in increasing community participation. Inhibiting factors include factors that influence the effectiveness of Bangkit Berdaya's program in increasing community participation in Kotabaru Subdistrict are residents who are less concerned with environmental conditions, there are people who do not want their land to be reduced in the implementation of government programs and there are 7 strategic issues that can be used in the application of the Bangkit Berdaya program in Jambi City.
\end{abstract}

Keywords: effectiveness and community participation

\footnotetext{
ABSTRAK

$E^{\prime}$ fektivitas Program Bangkit Berdaya dalam meningkatkan partisipasi masyarakat Di Kecamatan Kotabaru Kota Jambi Provinsi Jambi. Penelitian ini dilatarbelakangi karena ketertarikan penulis meneliti terhadap permasalahan yang timbul mengenai Efektivitas Program Bangkit Berdaya. Dari hasil wawancara dan observasi awal, penulis menemukan masalah Kurangnya partisipasi masyarakat di Kecamatan Kotabaru dalam pembangunan sarana prasarana di lingkungan kelurahan.
} 
Penelitian ini bermaksud untuk mengetahui sejauh mana efektivitas Program Bangkit Berdaya, faktor pendukung dan penghambat, serta strategi dalam penerapan Program Bangkit Berdaya di kecamatan Kotabaru, menggunakan teori Efektivitas yang dikemukakan oleh Gibson, Donnely dan Ivancevich Metode penelitian yang digunakan dalam penyusunan tesis ini adalah metode penelitian deskriptif, dengan pendekatan kualitatif. Data diperoleh adalah melalui studi pustaka, observasi, dokumentasi wawancara.

Hasil penelitian menunjukkan efektivitas Program Bangkit Berdaya menunjukkan hasil yang baik dalam meningkatkan partisipasi masyarakat. Faktor penghambat antara lain Faktor faktor yang memengaruhi efektivitas Program Bangkit Berdaya dalam meningkatkan partisipasi masyarakat di Kecamatan Kotabaru adalah adanya warga yang kurang peduli dengan kondisi lingkungan, ada masyarakat yang tidak ingin tanah miliknya menjadi berkurang dalam pelaksanaan program pemerintah dan ada 7 isu strategis yang dapat digunakan dalam penerapan Program Bangkit Berdaya di Kota Jambi .

Kata kunci: efektivitas dan partisipasi masyarakat

\section{PENDAHULUAN}

P erkembangan kota memberikan berbagai dampak bagi kehidupan masyarakatnya, dampak itu bisa berupa dampak positif dan dampak negatif, jika di kota Besar perencanaan pengembangan kawasan eksklusif. Pembangunan perkotaan tidak terlepas dari ruang yang harus di manfaatkan sehingga harus selalu mengacu pada kebijakan penataan ruang kawan yang dinamis dan responsif terhadap kebutuhan masyarakat. kebutuhan tersebut adalah agar semua anggota masyarakat dapat menghuni kota yang layak huni.

Kota Jambi yang menjadi pusat perdagangan dan jasa serta industri. Dalam perekonomian daerah cukup menonjol sebagai salah satu sektor yang mampu menyerap tenaga kerja. Berdasarkan rencana kebijakan daerah Provinsi Jambi menyebutkan bahwa kawasan perkotaan merupakan ruang yang diperuntukan untuk pengelompokan perumahan penduduk di dalamnya sarana prasarana sosial ekonomi masyarakat dengan dominasi kegiatan usaha nonpertanian. Ruang ini dipersiapkan untuk menampung kegiatan perumahan pada saat sekarang atau masa mendatang.

Kota Jambi memiliki 11 kecamatan dan 62 kelurahan. Kecamatan tersebut adalah Telanaipura, Jambi Selatan, Jambi Timur, Pasarjambi, Pelayangan, Danauteluk, Kotabaru, Jelutung, Alambarajo, Danausipin, dan Paalmerah.

Ketidakmerataan pembangunan telah menyebabkan tidak terpenuhinya sasaran layanan aksesibilitas sarana dan prasarana, Lingkungan dan sanitasi yang baik. Pada Dasarnya disesabkan kurangnya peranan masyarakat dalam memberikan masukan/ usulan terkait pada perencanaan pembangunan wilayah baik di tingkat kelurahan, kecamatan hingga di tingkat kota, dan terkadang usulan yang ada minim pendanaan karena tidak terakomodasi dalam anggaran.

Berdasarkan rencana kebijakan daerah Provinsi Jambi, diketahui bahwa Kota Jambi sebagai ibu kota provinsi mengemban amanat sebagai pusat pelayanan Nasional. Kota Jambi diarahkan sebagai pusat aktivitas sekunder dan tersier yang mengandung artian bahwa kebutuhan fasilitas perkotaan untuk Kota Jambi adalah permukiman perkotaan dengan intensitas dan fasilitas yang meliputi listrik air bersih drainase, pembuangan air kotor dan jaringan telekomunikasi.

Permasalahan kesenjangan pembangunan di Kota Jambi diperlukan penanganan yang serius dari pemangku kepentingan. Berpijak dari salah satu misi kepala daerah Kota Jambi untuk periode 2013-2018 adalah pembangunan infrastruktur perkotaan yang 
merata dan berwawasan lingkungan. Guna mewujudkan misi membangun infrastruktur perkotaan yang merata dan berwawasan lingkungan, Pemerintah Kota Jambi telah mengambil langkah-langkah untuk menyelesaikan permasalahan tersebut sebagai upaya mempercepat pembangunan yang merata Khususnya melalui kegiatan Bangkit Berdaya (Bangun Kelurahan secara Intensif dan terpadu Berazaskan Swadaya)

Berdasarkan Peraturan Wali Kota Jambi No. 42 Tahun 2015 juncto Peraturan Wali Kota Jambi No. 21 Tahun 2017 tentang Petunjuk Teknis Bangun Kelurahan Secara Intensif dan Terpadu Berdasarkan Swadaya, merupakan upaya pemerataan pembangunan di seluruh sektor pendukung aktivitas sosial dan ekonomi masyarakat pada lingkungan rukun tetangga dengan melibatkan partisipasi masyarakat dalam wilayah rukun tetangga, sehingga dapat meningkatkan pertumbuhan ekonomi dan pembangunan yang berwawasan lingkungan untuk mendukung Kota Jambi sebagai pusat perdagangan barang dan jasa berbasis masyarakat dengan berakhlak dan berbudaya.

Program Bangkit Berdaya ini memiliki sasaran pelaksanaan untuk meningkatkan jumlah permintaan dan usulan pembangunan masyarakat yang dapat diakomodasi oleh Pemerintah Kota Jambi serta meningkatkan partisipasi swadaya masyarakat dengan bergotong royong. Program ini diharapkan mampu menciptakan pembangunan yang merata, berbasis kepada kebutuhan masyarakat di wilayah kecamatan dan kelurahan supaya fokus pada pengembangan sarana dan prasarana dan utilitas masyarakat.

Prinsip pelaksanaan Program Bangkit Berdaya adalah:

1. Keadilan;

Menekankan pada aspek pemerataan, tidak diskriminatif dan seimbang antara hak dan kewajiban;

\section{Kemanfaatan;}

Dilaksanakan dengan memperhatikan kegunaan atau fungsi dari barang/ ruang/kondisi yang diperbaiki atau diganti;

3. Keterpaduan;

Mengintegrasikan berbagai komponen terkait sehingga dapat berjalan secara terkoordinasi dan sinergis;

4. Kemitraan;

Dalam upaya meningkatkan kesejahteraan masyarakat pada umumnya dibutuhkan kemitraan dengan berbagai pihak;

5. Keterbukaan;

Pihak-pihak yang terkait dalam kegiatan ini berhak mendapatkan informasi yang benar dan bersedia menerima masukan bagi keberhasilan pelaksanaan kegiatan;

6. Akuntabilitas;

Berbagai sumber daya yang digunakan dengan penuh tanggung jawab dan dapat dipertanggungjawabkan secara teknis maupun administratif;

7. Partisipasi;

Pelaksanaan kegiatan dilaksanakan dengan melibatkan unsur masyarakat termasuk dunia usaha dengan mendayagunakan berbagai sumber daya yang dimiliki;

8. Keberlanjutan;

Dilaksanakan secara berkesinambungan untuk mencapai kesejahteraan dan kemandirian.

Bangkit Berdaya ditujukan untuk mendorong percepatan pembangunan sarana dan prasarana lingkungan Rukun Tetangga (RT) dalam Wilayah Kota Jambi dan untuk mendorong partisipasi masyarakat dalam pembangunan kingkungan. Sasaran bantuan material/bahan bangunan adalah kelompok rukun tetangga dalam wilayah Kota Jambi yang telah mengususlkan 
rencana penggunaan bantuan material/ bahan bangunan dimaksud dan telah masuk dalam data pokok hasil usulan musyawarah perencanaan pembangunan (Musrenbang)

\section{Rumusan Masalah}

1. Bagaimana efektivitas Program Bangkit Berdaya dalam meningkatkan partisipasi masyarakat Kota Jambi Provinsi Jambi ?

2. Apa faktor-faktor yang menghambat efektivitas Program Bangkit Berdaya dalam meningkatkan partisipasi masyarakat Kota Jambi Provinsi Jambi?

3. Bagaimanakah strategi untuk meningkatkan efektivitas Program Bangkit Berdaya dalam meningkatkan partisipasi masyarakat Kota Jambi Provinsi Jambi?

\section{KAJIAN PUSTAKA}

\section{Efektivitas}

Pada pembahasan konsep efektivitas peneliti akan membahas mengenai efektivitas menurut pandangan para ahli dan ukuran ukuran dalam mengukur efektivitas. Dalam kehidupan bernegara kata efektivitas sering digunakan oleh institusi pemerintah dan masyarakat sebagai customer pemerintah. Efektivitas merupakan bagian atau unsur yang menjadi tolak ukur apakah suatu prgram yang dilaksanakan berhasil atau kurang berhasil. Menurut Mahmudi (2010;86) efektivitas merupakan hubungan Antara output dengan tujuan, semakin besar kontribusi output terhadap capaian tujuan, maka semakin efektif organisasi, program dan kegiatan. Sejalan dengan hal tersebut, Makmur (2011: 6) mengemukakan bahwa:

"Efektivitas berarti kegiatan dilakukan secara efektif di mana dalam proses pelaksanaannya senantiasa menampakkan ketepatan antara harapan yang kita inginkan dengan hasil yang di capai. Maka dengan efektivitas dapat dikatakan sebagai ketepatan, harapan, implementasi dan hasil yang di capai".

Kemudian ukuran besarnya efektivitas dapat menunjukkan tingkat pencapaian tujuan suatu organisasi, dan pelaksanaan fungsi organisasi untuk mencapai tujuan sebagaimana Tankilisan (2005: 139) menyampaikan:

Efektivitas organisasi menunjuk pada tingkat jauh organisasi yang melaksanakan kegiatan dan fungsi fungsinya sehingga tujuan yang ditetapkan dapat tercapai dengan menggunakan secara optimal alatalat dan sumber-sumber yang ada. Hal tersebut menyangkut dua aspek. , yaitu (1) tujuan organisasi, (2) pelaksanaan fungsi atau cara untuk mencapai tujuan tersebut

Pandangan tersebut berarti apabila tingkat pencapaian tujuan suatu organisasi tinggi maka semakin besar hasil capaian tujuan dan semakin efektif pelaksanaan fungsi fungsi, sehingga semakin besar efektivitas organisasi.

Dari beberapa pendapat di atas, dipahami bahwa efektivitas dalam proses sutu program tidak dapat mengabaikan target sasaran yang telah ditetapkan. Keberhasilan program dapat tercapai dengan tetap memperhatikan segi kualitas pelaksanaan program itu sendiri. Efektivitas merupakan suatu konsep penting karena mampu memberikan gambaran mengenai keberhasilan suatu program. Apakah tujuan program tersebut dapat tercapai sesuai target yang ditentukan atau tidak.

\section{Analisis SWOT}

SWOT adalah singkatan dari kata Strength (Kekuatan), Weakness (kelemahan) Opportunity (Peluang) dan Threat (ancaman). Analisis SWOT adalah identifikasi untuk melihat strategi berdasarkan hubungan unsur unsur pendukung. Menurut freddy rangkuti (2008: 18) analisis ini didasarkan 
pada hubungan atau interaksi antara unsur-unsur internal, yaitu kelemahan dan kekuatan terhadap unsur-unsur eksternal, yaitu peluang dan ancaman. Diagram dari analisis SWOT yang dikemukakan Rangkuti dapat dilihat pada gambar 1.

Analisis SWOT dapat dibagikan dalam lima langkah yaitu:

1. menyiapkan sesi SWOT;

2. mengidentifikasi kelemahan dan kekuatan;

3. mengidentifikasi kesempatan dan ancaman;

4. melakukan peringkat (ranking) terhadap kekuatan dan kelemahan;

5. menganalisis kekuatan dan kelemahan.

Manfaat analisis SWOT, yaitu untuk meningkatkan pengetahuan dan pemahaman organisasi terhadap tujuan dan arah yang akan dicapai dengan memperhitungkan faktor kekuatan, kelemahan, peluang dan ancaman yang mungkin saja terjadi. Salah satu proses dalam konsep manajemen adalah menyusun faktor penentu keberhasilan yang diawali dengan mengkaji lingkungan strategis yang meliputi kondisi, situasi, keadaan, peristiwa, dan pengaruh lingkungan baik eksternal maupun internal mempunyai dampak pada kinerja seluruh komponen yang terlibat.

Analisis lingkungan strategis adalah menyusun asumsi asumsi strategis dan mengujinya dengan visi misi untuk memperoleh faktor penentu keberhasilan, pelaksanaan analisis lingkungan strategi merupakan bagian dari komponen perencanaan strategis dan merupakan suatu proses untuk selalu menempatkan organisasi pada posisi strategis.

Analisis lingkungan internal adalah analisis yang digunakan untuk mengenal faktor-faktor yang memengaruhi perkembangan organisasi yang ada dalam tubuh organisasi baik itu berupa kekuatan (Strength) organisasi maupun kelemahan (weakness) organisasi.analisis lingkungan internal dilakukan dalam rangka mengidentifikasi isu-isu strategis dalam diri organisasi untuk mencapai sasaran.

Analisis faktor Eksternal Adalah analisis yang digunakan untuk mengenal faktorfaktor yang memengaruhi dari luar baik itu berupa peluang (opportunity) maupun ancaman (Threat).

Untuk menampilkan lingkungan strategis digunakan matriks SWOT sebagai berikut.

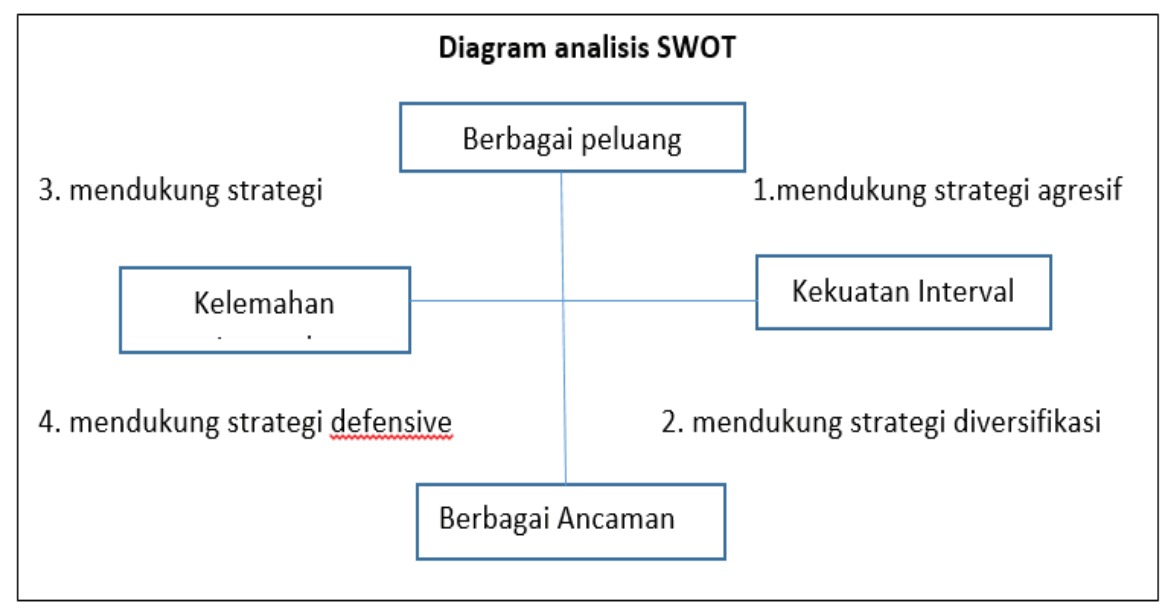

Gambar 1

Diagram Analisis SWOT

Sumber: Rangkuti 2008: 19 
Tabel 1 Matriks SWOT

\begin{tabular}{|c|c|c|}
\hline EFAS IFAS & Strenght (S) & Weakness (W) \\
\hline 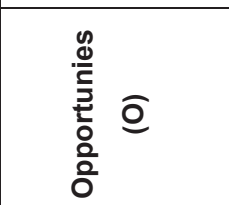 & $\begin{array}{l}\text { Strategi SO } \\
\text { Memanfaatkan potensi } \\
\text { untuk menciptakan } \\
\text { peluang }\end{array}$ & $\begin{array}{l}\text { Strategi WO } \\
\text { Meminimalkan kelemahan } \\
\text { untuk menciptakan peluang }\end{array}$ \\
\hline 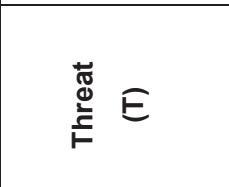 & $\begin{array}{l}\text { Strategi ST } \\
\text { Memanfaatkan potensi } \\
\text { untk menghadapi } \\
\text { ancaman }\end{array}$ & $\begin{array}{l}\text { Strategi WT } \\
\text { Meminimalkan kelemahan } \\
\text { untuk menghadapi } \\
\text { ancaman }\end{array}$ \\
\hline
\end{tabular}

Sumber: Rangkuti 2008: 31

\section{a. Strategi SO}

Strategi ini dibuat berdasarkan jalan pikiran dengan memanfaatkan seluruh kekuatan untuk merebut dan memanfaatkan peluang sebesarbesarnya.

b. Strategi ST

Strategi ini adalah strategi dalam menggunakan kekuatan yang dimiliki untuk mengatasi ancaman

c. Strategi WO

Strategi ini diterapkan berdasarkan pemanfaatan peluang yang ada dengan meminimalkan kelemahan yang ada.

d. Strategi WT

Strategi ini didasarkan pada kegiatan yang bersifat defensif dan berusaha meminimalkan kelemahan yang ada serta menghindari ancaman

Melalui matriks tersebut didapatkan isu isu strategis terpilih yang teridentifikasi dan selanjutnya dievaluasi menjadi temuan isu strategis. Analisis SWOT dapat dicermati melalui perubahan lingkungan yang mengadaptasi serta menyesuaikan perubahan kebutuhan dan keinginan publik. Melalui analisis SWOT akan dapat dilakukan penyesuaian Visi, Misi dan tujuan sesuai dengan perubahan dan harapan publik.

\section{HASIL PENELITIAN}

\section{Produktivitas}

Suatu program akan berjalan baik apabila menghasilkan manfaat yang baik dan mampu meningkatkan kuantitas dan kualitas kinerja. Pada Program Bangkit Berdaya ini manfaatnya harus dapat dilihat dan dirasakan oleh masyarakat.

Penerapan Program Bangkit Berdaya di Kecamatan Kotabaru menjadi penting dalam pencapaian sasaran program itu sendiri, yaitu meningkatkan partisipasi masyarakat di Kecamatan Kotabaru Kota Jambi Provinsi Jambi. Ketika di konfirmasi ke Kecamatan Kotabaru maka penulis mendapatkan jawaban bahwa Peraturan Wali kota tentang Bangkit Berdaya ini mulai dilaksanakan sejak tahun 2015 dan baru dilaksanakan di Kecamatan Kotabaru mulai tahun 2018 dan diharapkan program itu dapat terus berjalan selain dari dirasakannya manfaat langsung, Program Bangkit Berdaya ini juga meningkatkan semangat gotong royong masyarakat di Kecamatan Kotabaru.

Berdasarkan keterangan yang yang di berikan oleh Camat Kecamatan Kotabaru Eryadi pada 27 Maret 2020, di mana beliau mengatakan bahwa:

Penerapan Program Bangkit Berdaya ini telah dilaksanakan oleh Kecamatan 
Kotabaru sejak tahun 2018, dan telah dirasakan manfaatnya bagi masyarakat di Kota Jambi , karena setelah penerapan program yang berdampak langsung pada masyarakat ini, maka dapat kita lihat sendiri bahwa program ini juga tidak terlepas dari partisipasi warganya, sehingga ketercapaian hasilnya tidak mengecewakan.

Selanjutnya Camat Kotabaru menyampaikan bahwa pelaksanaan program di kecamatannya berdampak baik pada output program itu sendiri.

Produktivitas penerapan Program Bangkit Berdaya ini terkait seberapa banyak hasil program yang sudah dilaksanakan dan diimplementasikan dalam rangka pelaksanaan Program Bangkit Berdaya di Kecamatan Kotabaru dan terlihat dari kualitas hasil program yang di berikan kepada masyarakat.

\section{Efisiensi}

Keberhasilan suatu program biasanya dipengaruhi oleh beberapa faktor, salah satunya, yaitu menghasilkan manfaat dengan biaya yang seminimal mungkin. Keberhasilan penerapan Program Bangkit Berdaya

Hal ini disebabkan kurangnya koordinasi antarinstansi pemerintah serta kurangnya sosialisasi program tersebut terhadap masyarakat. Pernyataan tersebut sebagaimana dikemukakan oleh Nico warga Kecamatan Kotabaru yang penulis wawancarai pada 23 April 2020 pada pukul 14.00 di rumah beliau:

"Pada dasarnya peraturan wali kota tentang Bangkit Berdaya bukanlah barang baru. Program tersebut sesungguhnya sangat padat karya namun kami sebagai masyarakat masih belum dapat secara lugas memahami caracara menerima dan memanfaatkannya. Bahkan mengusulkannya pun kami kurang paham dikarenakan masih banyak warga yang belum menerima sosialisasi tentang program tersebut. Namun untuk program dari RT kami yang sudah disetujui kami lihat bahwa memang program ini hasilnya sangat memuaskan. Warga sangat terbantu dengan batuan material ini. Dan kami jadi bisa membangun jalan setapak contohnya. Sangat meringankan sekali."

Lebih lanjut S (warga RT 18) yang penulis wawancarai pada 25 April 2020 di rumahnya menyatakan:

Pada prinsipnya kami sangat mendukung program tersebut karena kami sebagai masyarakat bisa mengusulkan apa saja sarana dan prasarana yang kami butuhkan untuk di bangun di wilayah kami. Dan dengan adanya program ini kami sebagai masyarakat pun akan turut berpartisipasi di dalam pembangunan maupun pemeliharaan infrastruktur tersebut.

\section{Kepuasan}

Kepuasan merupakan indikator yang penting dalam menentukan keberhasilan suatu program. Kepuasan dalam hal ini digambarkan melalui manfaat yang dirasakan oleh masyarakat, baik secara langsung maupun tidak langsung dengan diterapkannya Program Bangkit Berdaya di Kecamatan Kotabaru ini, setiap Rukun tetangga (RT) dapat membangun fasilitas di lingkungannya masing masing dan pengerjaannya pun dilakukan oleh masyarakat sendiri, sehingga masyarakat dapat memastikan bagaimana hasil pembangunan yang dilaksanakan secara gotong royong tersebut.

\section{Adaptasi}

Adaptasi merupakan kemampuan dari organisasi dalam merespons setiap perubahan yang terjadi di lingkungan organisasi baik itu perubahan yang berfokus pada masyarakat ataupun perubahan pada keadaan organisasi pemerintah sendiri. 
Dan melihat keadaan di lapangan bahwa masyarakat sangat antusias dan dapat menerima program ini dan meresponsnya dengan baik dan juga masyarakat dapat melihat hasil dari program tersebut.

\section{Perkembangan}

Setiap program harus dapat berkembang dan mempunyai kemampuan untuk bertahan. Secara efektif dan efisien dalam menghadapi setiap tuntutan dari masyarakat. Secara khusus Pemerintah Kota Jambi memberikan perhatian kepada kebutuhan utilitas masyarakat dengan memberikan kebijakan Program Bangkit Berdaya yang secara langsung memberikan manfaat kepada masyarakat di Kecamatan Kotabaru. Apabila suatu Program dapat berkembang dan mampu mempertahankan program dan kegiatan yang direncanakannya, maka menandakan bahwa kinerja yang dilakukan mampu mencapai sasaran dan tujuan yang diinginkan sebagaimana tertuang dalam Peraturan Wali Kota Jambi tentang pelaksanaan Program Bangkit Berdaya, yaitu untuk meningkatkan partisipasi masyarakat. Dalam konteks penerapan Program Bangkit Berdaya keberhasilan akan sangat bergantung pada proses penyusunan, hingga pelaksanaannya, artinya keberhasilan setiap tahapan program tersebut akan berdampak pula pada praktiknya secara nyata.

Berdasarkan hasil penelitian di Kecamatan Kotabaru, penerapan Program Bangkit Berdaya yang berperan dalam meningkatkan partisipasi masyarakat dalam pembangunan sarana dan prasarana sudah efektif. Hal ini di perkuat dengan pernyataan camat Kotabaru bahwa: " sejauh ini masyarakat sudah lebih aktif dalam mengajukan usulan, lalu dalam proses pelaksanaannya, serta bentuk partisipasi lain. Karena partisipasi tidak hanya diukur dalam bentuk materi saja. Sehingga menggerakkan masyarakat untuk turun langsung secara bergotong royong juga termasuk bentuk perhatian dan partisipasi masyarakat terhadap lingkungan. Sehingga program ini dinilai berhasil dan patut menjadi program prioritas daerah."

\section{Faktor-Faktor yang Menghambat Program Bangkit Berdaya dalam Meningkatkan Partisipasi Masyarakat}

Beberapa faktor yang memengaruhi Program Bangkit Berdaya yaitu: faktor kurangnya informasi serta sosialisasi terkait Program Bangkit Berdaya yang dapat di akses masyarakat, kurangnya sumber daya manusia yang dapat mengerti dan paham terkait pelaporan dan proses penggunaan anggaran dalam hal ini adalah pihak yang ditunjuk oleh kecamatan sebagai penyedia material bahan bangunan, terbatasnya anggaran pemerintah dalam Program Bangkit Berdaya.

1. Berbicara tentang informasi tidak akan pernah terlepas dari faktor sosialisasi. Apabila informasi telah tersampaikan tepat sasaran secara lugas maka semuanya akan berjalan dengan baik. Sehubungan dengan hal tersebut efektivitas Program Bangkit Berdaya sangat bergantung pada aparatur pemerintah dalam menyampaikan informasi serta sosialisasi kepada masyarakat sehingga poin-poin dari Program Bangkit Berdaya ini dapat berjalan dengan baik.

2. Kurangnya sumber daya manusia yang memahami pelaporan dan proses penggunaan anggaran dalam hal ini adalah pihak yang ditunjuk oleh kecamatan sebagai penyedia material bahan bangunan. Program Bangkit Berdaya yang elah berjalan memiliki persoalan sendiri terkait bagaimana cara melaporkan pertanggungjawaban anggaran. Di sinilah perlunya pendampingan kuat dari unsur pemerintah kecamatan yang notabene lebih mengerti bagaimana SOP pembuatan laporan tersebut sehingga 
masyarakat dan pihak ketika sebagai penyedia bahan material tidak lagi bingung dalam menyusun laporan dan menghadapi pemeriksaan.

3. Terbatasnya anggaran pemerintah dalam mengakomodir permintaan warga dalam satu tahun berjalan, namun pemerintah dalam hal ini mengusahakan agar Program Bangkit Berdaya tersebut tetap dapat menjadi prioritas.

Di Kota Jambi khususnya di Kecamatan Kotabaru yang merupakan daerah yang sedang berkembang dalam hal pembangunan masih sangat dibutuhkannya pembangunan sarana prasarana baik itu jembatan jalan MCK, saluran drainase dan lain -lain. Di mana masyarakat masih sangat membutuhkan sarana prasarana tersebut hanya saja pemerintah masih memiliki keterbatasan baik itu waktu, anggaran dan SDM sehingga dikeluarkannya Program Bangkit Berdaya tersebut guna mengakomodir kebutuhan masyarakat yang tidak terakomodasi dalam pembangunan.

\section{Strategi untuk Meningkatkan Efektivitas Program Bangkit Berdaya dalam Meningkatkan Partisipasi Masyarakat Kota Jambi}

Strategi merupakan langkah-langkah yang diambil agar tercapai tujuan yang diinginkan, peneliti menggunakan metode analisis swot (strength, opportunities, weakness, threats). Metode tersebut bermaksud agar hasil penelitian ini dapat memberikan strategi dalam meningkatkan partisipasi masyarakat dalam Program Bangkit Berdaya. Peneliti menggunakan analisis SWOT (strength, opportunities, weakness, threats) sebagai alat dalam menentukan strategi yang tepat untuk mengukur efektivitas Program Bangkit Berdaya. Analisis ini akan menentukan langkah-langkah yang harus diambil dalam memecahkan masalah karena teruji dengan kondisi eksternal dan internal masyarakat di Kota Jambi.
Kondisi secara internal, yaitu kekuatan (strength) dan kelemahan (weakness). sedangkan secara eksternal adalah peluang (opportunities) dan ancaman (threats) akan menghasilkan ide-ide serta tujuan yang membantu mengidentifikasi kondisi kondisi permasalahan.

\section{- Kekuatan (Strength)}

Dari hasil penelitian di lokasi penelitian di temukan faktor internal berupa strength dalam meningkatkan partisipasi masyarakat antara lain:

a. Jumlah pegawai yang cukup memadai. Pegawai kecamatan di Kota Jambi yang mengerti tentang Program Bangkit Berdaya dalam segi jumlah sudah cukup memadai.

b. Adanya aturan yang melekat sebagai payung hukum dalam pelaksanaan Program Bangkit Berdaya.

c. Semangat kerja yang tinggi dari masyarakat menjalankan tugas dengan penuh semangat walaupun mereka masih dalam keterbatasan waktu, tenaga dan materi namun tetap melaksanakan kegiatan dengan penuh tanggung jawab.

d. Program ini diterima dengan baik oleh masyarakat

\section{- Kelemahan (Weakness)}

Dari faktor internal selain adanya kekuatan juga terdapat kelemahan yang dapat menghambat peningkatan partisipasi masyarakat. Setelah penelitimengidentifikasi terdapat beberapa kelemahan seperti:

1. Lemahnya keingintahuan masyarakat dalam mencari informasi tentang Program Bangkit Berdaya.

2. Kurangnya sosialisasi peraturan Wali Kota Jambi No. 21 Tahun 2017 tentang Petunjuk Teknis Bangun Kelurahan Secara Intensif dan Terpadu Berdasarkan Swadaya.

3. Kondisi masyarakat yang kurangnya sumber daya manusia yang mengerti 
tentang pelaporan dan proses penggunaan anggaran.

4. Lemahnya pengawasan yang dilakukan terhadap pelaksanaan kegiatan tersebut sehingga masih ada beberapa kekurangan baik pada spesifikasi bangunan dan lain-lain.

\section{- Peluang (Opportunities)}

a. Adanya tingkat kesadaran masyarakat untuk meningkatkan taraf hidup di mulai dari mengingatkan sarana prasarana.

b. Jelasnya visi dan misi dari Program Bangkit Berdaya

\section{- Ancaman (Threats)}

a. terbatasnya anggaran sehingga mengakibatkan masyarakat membutuhkan cukup banyak dana pribadi.

b. Banyak usulan yang tidak dapat diakomodasi oleh pemerintah.

c. Adanya daerah yang tidak dapat diakomodasi usulannya dikarenakan tidak sesuai dengan peraturan.

\section{SIMPULAN}

Berdasarkan hasil wawancara penulis dengan informan dan tinjauan literatur yang dilakukan serta hasil analisis deskriptif dengan menggunakan analisis SWOT (strength, weakness, opportunity, threats) serta pengujian Litmus yang diuraikan penulis dalam pembahasan, maka dapat disimpulkan beberapa hal sebagai berikut

1. Efektivitas Program Bangkit Berdaya dalam meningkatkan partisipasi masyarakat di Kecamatan Kotabaru Kota Jambi sudah mencapai tujuannya, dikatakan demikian bahwa melihat hasil penelitian di lapangan bahwa program ini telah meningkatkan partisipasi masyarakat dalam pelaksanaannya, selain jumlah RT pelaksana Program Bangkit Berdaya yang meningkat pada berikutnya, ada pula peningkatan kesadaran masyarakat dalam berpartisipasi pada program tersebut guna meningkatkan spesifikasi bangunan sarana prasarana yang menjadi output program.

2. Faktor faktor yang memengaruhi efektivitas Program Bangkit Berdaya dalam meningkatkan partisipasi masyarakat di Kecamatan Kotabaru adalah adanya warga yang kurang peduli dengan kondisi lingkungan, ada masyarakat yang tidak ingin tanah miliknya menjadi berkurang dalam pelaksanaan program pemerintah,

3. Adapun strategi untuk meningkatkan partisipasi masyarakat adalah

a. Melakukan upaya meningkatkan kesadaran masyarakat terhadap manfaat Program Bangkit Berdaya

b. Meningkatkan sumber daya aparatur yang dapat membantu masyarakat dalam proses pengajuan hingga laporan kegiatan

c. Meningkatkan sosialisasi terkait Program Bangkit Berdaya.

d. Mengupayakan adanya prioritas bagi RT(Rukun tetangga) yang sangat membutuhkan bantuan.

e. Meningkatkan jumlah RT (Rukun Tetangga) yang dapat diakomodasi dalam pelaksanaan Program Bangkit Berdaya.

\section{SARAN}

Demi penyelenggaraan pemerintahan yang baik khususnya dalam meningkatkan partisipasi masyarakat di lingkungan Kecamatan Kotabaru Kota Jambi dan dari simpulan yang telah dikemukakan di atas maka peneliti dapat memberikan saran yang mungkin menjadi masukan bgi pihak pihak yang berkepentingan. Adapun saran tersebut antara lain sebagai berikut. 
a. Meningkatkan sosialisasi melalui media massa ataupun media sosial tentang tahapan dan cara usulan Program Bangkit Berdaya kepada masyarakat ataupun melaksanakan sosialisasi program secara berjenjang hingga ke tingkat RT dan masyarakat.

b. Memberikan pelatihan kepada sumber daya manusia yang terlibat terkait dengan pembuatan SOP (Standar Operasional Prosedur) penyusunan laporan pertanggungjawaban program, Bangkit Berdaya.

c. Melakukan efisiensi anggaran terhadap program dan kegiatan di dalam lingkungan pemerintah yang saat ini belum menjadi skala prioritas sehingga pembangunan infrastruktur melalui Program Bangkit Berdaya dan mengupayakan program ini dapat menjadi program prioritas daerah.

\section{DAFTAR RUJUKAN}

Adisubrata, Winarna Surya. 2002. Otonomi Daerah di Era Reformasi. Unit Yogyakarta: Penerbit dan Percetakan (UPP) AMP YKPN.

Alsa, Asmadi, 2004, Pendekatan Kualitatif dan Kuantitatif serta Kombinasinya dalam penelitian Psikologi, Yogyakarta.

Arikunto, Suharsimi. 2006. Prosedur Penelitian: Suatu Pendekatan Praktik. Jakarta: Asdi mahasatya.

Bryson, John M. 2011. Perencanaan Strategis Bagi Organisasi Sosial. Jakarta: Pustaka Pelajar.

Creswell. Jhon W. 2009. Qualitative, Quntitative and Mixed Methods Approaches, SAGE Publication Inc, California.

Denpasar.Departemen Pendidikan dan Kebudayaan. (1995). Kamus Besar Bahasa Indonesia, Jakarta: Balai Pustaka

Ermaya Suradinata, 1998, Manajemen Pemerintahan dan Otonomi Daerah, Bandung: Ramadan.
Hamel, G dan Prahalad, C, K. 1995. Kompetisi Masa Depan. Jakarta: Bina Rupa Aksara

Hubeis, Musa dan Najib, Mukhamad. 2008. Manajemen Stratejik dalam Pengembangan Daya Saing Organisasi. Bogor: PT Elex Media Komputindo.

Hatten, Kenneth J dan Mary Louise Hatten. 1988 Effective Strategic Management. Englewood Cliffs: Prentice Hall.

Islamy, Irfan, 2007. Prinsip-prinsip Perumusan Kebijaksanaan Negara. Jakarta: Bumi Aksara.

Manan, Bagir. 2004. Perkembangan UndangUndang Dasar 1945. Jakarta: PT Gramedia Pustaka Utama.

Marrus, Stephanie K.2002.Building The Strategic Plan: Find Analyze, And Present The Right Information. USA: Wiley.

Moleong, Lexy J. 2002 Metodologi Penelitian Kualitatif. Bandung: PT Remaja Rosdakarya.

Nazir, Moh. 2009. Metode Penelitian. Jakarta: Ghalia Indonesia.

Ndraha, Taliziduhu. 2006. Kybernologi (Ilmu Pemerintahan) Jilid 3. Jakarta: Rineka Cipta.

Nurcholis, Hanif. 2005. Teori dan Praktik Pemerintahan dan Otonomi Daerah. Jakarta: PT Grasindo

Pamudji, S. 1994. Perbandingan Pemerintahan. Jakarta: Bumi Aksara.

Quinn (1999) Diagnosing and Changing Organizational Culture: Based on the Competing Values Framework. Reading, Massachusetts: Addison Wesley

Rangkuti, Freddy. 2014. Analisis SWOT: Teknik Membedah Kasus Bisnis. Jakarta: PT Gramedia Pustaka Utama.

Saleh dkk. 1999. Konsep dan Strategi Peningkatan Produksi Pangan. Bogor: Pusat Penelitian dan Pengembangan Tanaman Pangan.

Siagian, Sondang P. 2002. Kiat Meningkatkan Produktivitas Kerja. Jakarta: Asdi Mahasatya.

Sugiyono. 2005. Memahami Penelitian Kualitatif. Bandung: CV Alfabeta. 
- 2010.Metode Penelitian Kuantitatif Kualitatif dan R\&D. Bandung: CV Alfabeta.

Tjokroamidjojo, Bintoro. 1998. Teori dan Strategi Pembangunan Nasional. Jakarta: CV Haji Mas Agung.

\section{Hasil Penelitian Sebelumnya}

Pertiwi, Chintya, 2019 Implementasi Program Pemerintah Kota Jambi Menuju Jambi Bangkit Berdaya

Asfar, La ode, 2017 Partisipasi masyarakat dalam pelaksanaan program pemberdayaan kampung dan kelurahan di Distrik Teluk Etna Kabupaten Kaimana

Ilyas, Muhammad, 2015 Strategi Pengembangan Pariwisata Kepulauan Togean di Kabupaten Tojo Una-Una

\section{Peraturan Perundang-Undangan}

Undang-Undang Dasar 1945

Undang-Undang No. 23 Tahun 2014 tentang Pemerintahan Daerah

Peraturan Pemerintah No. 17 Tahun 2018 tentang Kecamatan
Peraturan Pemerintah No. 12 Tahun 2019 tentang pengelolaan keuangan daerah

Permendagri No. 130 Tahun 2018 tentang Kegiatan Pembangunan Sarana Prasarana Kelurahan Dan Pemberdayaan Masyarakat Di Kelurahan

Peraturan Daerah Kota Jambi No. 9 Tahun 2013 tentang Rencana Tata Ruang Wilayah Kota Jambi Tahun 2013-2033 Lembaran Daerah Kota Jambi No. 9 Tahun 2013

Peraturan Wali Kota Jambi No. 42 Tahun 2015 juncto Peraturan Wali Kota Jambi No. 21 Tahun 2017 tentang petunjuk teknis Bangun Kelurahan Secara Intensif dan Terpadu berdasarkan Swadaya

\section{Internet}

http://id.wikipedia.org/wiki/Daftar_ Kecamatan_Kelurahan_di_Kota_Jambi

Prinsip pelaksanaan Bangkit Berdaya Kota Jambi http://jambikota.go.idd/new/program-bangkit-berdaya/ 